\title{
Physical mapping of ribosomal DNA and genome size in diploid and polyploid North African Calligonum species (Polygonaceae)
}

\author{
Hassen GOUJA ${ }^{1,2,3}$, Teresa GARNATJE ${ }^{4}$, Oriane HIDALGO ${ }^{2,5}$, Mohamed NEFFATI ${ }^{1}$, Aly \\ RAIES $^{3}$ and SÒNIA GARCIA ${ }^{2 *}$
}

${ }^{1}$ Pastoral Ecology Laboratory, Arid Regions Institute, Médenine, Tunisia

${ }^{2}$ Laboratori de Botànica-Unitat associada CSIC, Facultat de Farmàcia, Universitat de Barcelona. Avinguda Joan XXIII s. n., 08028 Barcelona, Catalonia, Spain

${ }^{3}$ Microbial and Biomolecular Laboratory, Faculty of Sciences of Tunis, University of Tunis El-Manar, El-Manar, Tunisia

${ }^{4}$ Institut Botànic de Barcelona (IBB-CSIC-ICUB), Barcelona, Catalonia, Spain

${ }^{5}$ Jodrell Laboratory, Royal Botanic Gardens, Kew, Richmond, Surrey TW9 3AB, United Kingdom

*Corresponding author: soniagarcia@ub.edu

Tel: 0034934024490

Fax: 0034934035879

Running title: Cytogenetics in Calligonum 


\begin{abstract}
Most Calligonum species are desert plants, characteristic of the Saharan bioclimatic region. All species karyologycally analysed until present have the basic chromosome number $x=9$ and comprise diploids, triploids and tetraploids. The Tunisian flora comprises diploid $C$. arich and $C$. azel, of restricted distribution, and the tetraploid $C$. comosum with wider distribution. Analyses of their karyotypes and polyploidisationlinked rDNA changes by orcein staining, fluorochrome banding with chromomycin $A_{3}$ and fluorescent in situ hybridisation with $5 \mathrm{~S}$ and $26 \mathrm{~S}$ ribosomal DNA probes have been performed. We report the chromosome number for $C$. arich $(2 n=18)$ as well as the diploid level for $C$. comosum for the first time. Chromosome counts have also verified the earlier described tetraploid cytotype $(2 n=36)$ of $C$. comosum. A general pattern of six GC-rich bands as well as two $35 \mathrm{~S}$ sites and four $5 \mathrm{~S}$ sites is described for Calligonum species at the diploid level although there is intraspecific variation regarding the site number in a second type of $A$. comosum, with one pair of 35S rDNA sites and two pairs of 5S rDNA sites. The tetraploid cytotype of $C$. comosum has undergone locus loss and genome downsizing. Genome size assessments confirmed previous data. Nonetheless, statistically significant differences were found depending on the type of tissue used for estimation. Measurements from seeds had always larger values than from leaves. The presence of cytosolic compounds in leaves, interfering with DNA staining, is discussed as a possible cause of the differences.
\end{abstract}

Key words: $5 \mathrm{~S}$ rDNA, 35S rDNA, cytogenetics, FISH, fluorochrome banding, genome organisation 


\section{Introduction}

Calligonum L. (Polygonaceae) is one of the dominant genera in active sand dunes, distributed in the North African desert, the desert sands of the Middle East, south Europe and in West and Central Asia (Mao and Pan 1986). China represents most of the distribution range of the genus with 23 species out of $60-80$ species in the world (Bao and Grabovskaya-Borodina 2003; Singh 2004). Many facts have caused the decline of the natural resources of Calligonum species (Liu et al. 2001) and some of them are considered even critically endangered, threatened with extinction, according to the criteria of the International Union for Conservation of Nature (IUCN 1997). The threats include overgrazing by the camel herds, use as firewood, and several other uses by Bedouins and local nomadic populations. Local healers have reported the chewed stems and leaves to cure toothache (Liu et al. 2001). Pharmacological and toxicological studies on Calligonum aerial parts showed anti-gastric, anti-hypertensive, high antimicrobial potential (Radhakrishnan et al. 1999; Zaki et al. 1984), anti-nociceptive and antiasthmatic activities (Islam et al. 1999; Liu et al. 2001). Extracts of Calligonum species are also described to reduce acute gastric ulcers (Liu et al. 2002) and protecting against toxic agents (Islam et al. 1999; Liu et al. 2001). They have also a great potential as forage and for halting desert encroachment (Badria et al. 2007).

Only three species of this genus have been found in the Tunisian desert, which play an important role in the Saharan bioclimatic region (Le Houérou 1959; Pottier-Alapetite 1979; Gouja et al. 2014). Calligonum comosum L'Hér. is a shrub of 1 to $2 \mathrm{~m}$ height with 
the widest geographic distribution (Le Houérou 1959). This plant is abundant in the North African desert, the desert sands of the Middle East and Pakistan, as well as the sand dunes in both Central and Eastern Arabia (Lipscombe 1984). Calligonum azel Maire is an endemic tree or tall shrub (up to 4-5 m) of Great Eastern Erg, with a prominent branching (Le Houérou 1959; Dhief et al. 2012). Calligonum arich Le Houér. is a tree up to 7-9 $\mathrm{m}$ tall, considered as a Tunisian endemic of the Great Erg Oriental (Le Houérou 1959; Pottier-Alapetite 1979; Gouja et al. 2014), with a prominent, non-thorned branching. The three Tunisian species are sometimes found in the same localities, although not intermixed as they occupy different dune slope positions (Le Houérou 1959).

In systematic and evolutionary studies of plants, karyological data are important and widely used to determine species relationships (Stebbins 1971; Hong 1990; Stuessy 2011; Garbari et al. 2012). Several karyological studies have been based on family Polygonaceae, despite its difficulty due to the usually small chromosome size (Mao et al. 1983; Wang and Yang 1985). Most chromosomal researches on this family were centred on Polygonum, Fagopyrum, Rheum and Rumex (Baltisberger and Widmer 2006; Hu et al. 2007). Different basic chromosome numbers have been recorded: $x=8,9$ and 10 were detected for Rumex (Bolkhovskikh et al. 1969), $x=11$ for Rheum (Darlington and Wylie 1955) and $x=8$ for Fagopyrum (Zhang 1998). Only $x=9$ has been reported for genus Calligonum, and chromosome counts have been already performed for 16 species to our knowledge (Mao et al. 1983; Wang and Yang 1985; Wang and Guan 1986; Ferchichi 1997) including diploid, triploid and tetraploid levels. Regarding Tunisian Calligonum, 
chromosome counts establish diploidy for $C$. azel and tetraploidy for C. comosum (Ferchichi 1997), while no data are available for $C$. arich. Genome size measurements are consistent with these results and suggest $C$. arich to be diploid (Gouja et al. 2014). Fluorescent in situ hybridisation (FISH) with ribosomal DNA (rDNA) probes provides useful markers for chromosome identification (Singh et al. 2001). In plants, FISH with ribosomal RNA (rRNA) genes as probes has been widely used for karyotyping (Raina et al. 2001), for studying genome organisation and chromosome evolution (Leitch and Heslop-Harrison 1993) and for understanding the systematic and evolutionary relationships between closely related species (Ali et al. 2000; Ran et al. 2001; Li and Zhang 2002). In family Polygonaceae few researches have been performed, which describe the numbers and locations of $5 \mathrm{~S}$ and $35 \mathrm{~S}$ (18S-5.8S-25S) rRNA genes for genera Fagopyrum, Persicaria and Rumex (Kim et al. 2006; Choi et al. 2008; Kikuchi et al. 2008; Sheng et al. 2013). However these genera are relatively phylogenetically distant from Calligonum (Schuster et al. 2013).

In this study, we investigate for the first time the abundance and distribution pattern of $5 S$ and $35 \mathrm{~S}$ rDNA loci on the chromosomes of three Calligonum species by FISH. The specific aims of this research are: a) to characterise the numbers and locations of $5 \mathrm{~S}$ and $35 \mathrm{~S}$ rDNA sites and b) to study the evolution of rDNA loci with polyploidy. Additionally, we have complemented a previous genome size study on this group (Gouja et al. 2014) by undertaking new assessments on these three Tunisian Calligonum species both in seed and in seedlings, in order to study the reach of intraspecific or interpopulation 
variability, if any, as well as to detect any significant difference on genome size estimation with respect to the tissue used.

\section{Materials and methods}

Plant materials

Seeds of three Calligonum species (C. arich, C. azel and C. comosum) for cytogenetics and genome size assessments were collected from the wild part of the desert in the Eastern Great Erg of Southern Tunisia. In this study, seeds were selected at three sites (El Borma, Tiaret and Kamour, places with the typical arid-type climate of dry and hot summers and cold winters) between years 1999 and 2012 (Table 1 and Fig. 1). These were washed and stored $\left(20^{\circ} \mathrm{C}, 30 \% \mathrm{H}\right)$ in the seed bank at the Pastoral Ecology Laboratory (PLE) of the Arid Regions Institute (Médenine, Tunisia) until further use. For flow cytometric measurements on leaf tissue, seedlings were obtained from seeds from the corresponding sites. Specimen vouchers of the studied material have been deposited in the herbarium of the University of Barcelona (BCN).

Chromosome preparations

Seeds were germinated on wet filter paper in Petri dishes in the dark at room temperature. Chemical scarification with sulfuric acid (96\%) for 30 min was applied to $C$. 
azel and C. arich seeds, before germination. In order to obtain mitotic chromosomes, $0.5-1 \mathrm{~cm}$ long root tips were collected from seedlings and the meristems pretreated in aqueous colchicine $(0.05 \% \mathrm{w} / \mathrm{v})$ for $3-4 \mathrm{~h}$ and then fixed in Farmer's fixative fluid (absolute ethanol : glacial acetic acid, $3: 1$ ) at $4^{\circ} \mathrm{C}$ for at least $4 \mathrm{~h}$ and later transferred to $70 \%$ ethanol. For chromosome counts, the fixed roots were hydrolyzed in $0.1 \mathrm{M}$ hydrochloric acid at $60^{\circ} \mathrm{C}$ for $1 \mathrm{~min}$, washed with water and then stained with acetic orceine (1\%) for 2-12 hours and squashed for observations. Each sampled population included 10 to 30 individuals. A minimum of 10 well spread metaphases were counted for each population. Photographs were taken with a digital camera (AxioCamHRm Zeiss) coupled on a Zeiss Axioplan microscope and images were analyzed with Axio Vision Ac software version 4.2

Chromosome preparations for fluorochrome banding and FISH were done using the airdrying technique of Geber and Schweizer (1987), with some modifications: root tips were washed with soft shaking in citrate buffer $(0.01 \mathrm{M}$ citric acid - sodium citrate, $\mathrm{pH}=$ 4.6) for 15 minutes, excised, and incubated in an enzyme solution [ $4 \%$ cellulase Onozuka R10 (Yakult Honsha), 1\% pectolyase Y23 (Sigma) and $4 \%$ hemicellulase (Sigma)] at $37^{\circ} \mathrm{C}$ for 20 to 25 minutes, depending on the species and meristematic thickness. Protoplasts were prepared applying gentle pressure (squash) to spread the chromosomes onto microscope slides, frozen at $-80 \circ \mathrm{C}$ overnight and after fast coverslip removal they were desiccated using absolute ethanol and drying for two days.

Fluorochrome banding 
In order to reveal GC-rich DNA bands, chromomycin $A_{3}(C M A)$ was used, following the protocols of Schweizer (1976) and Cerbah et al. (1995) with minor modifications: the slides were incubated in Mcllvaine buffer, $\mathrm{pH}=7(0.1 \mathrm{~g} / \mathrm{L}$ in Mcllvaine buffer, $\mathrm{pH}=7)$ for $15 \mathrm{~min}$; stained with CMA (5 mmol/L MgSO 4$)$ for 60 to $90 \mathrm{~min}$; rinsed in the latter buffer; counterstained with methyl green $(0.1 \%$ in Mcllvaine buffer, $\mathrm{pH}=5.5)$ for $10 \mathrm{~min}$; rinsed in Mcllvaine buffer, $\mathrm{pH}=5.5$; and mounted in Citifluor AF1 (glycerol/PBS solution).

Labelling of rDNA probes and FISH

For hybridisation experiments we have mostly used the same slides than for fluorochrome banding with CMA after destaining with fixative, dehydration through an ethanol series (70\%, $90 \%$ and $100 \%)$, and drying for two days. The probe used for $35 \mathrm{~S}$ rDNA localization was a plasmid carrying a $2.5 \mathrm{~kb}$ insert of $26 \mathrm{~S}$ rRNA gene from Lycopersicum esculentum Mill. labeled with Cy3 (Jena Biosciences) using the Nick Translation Mix (Roche). The 5S rDNA probe was an approximately $0.7 \mathrm{~kb}$-long trimer of 5S rRNA genes from Artemisia tridentata Nutt., labeled with Green dUTP (Abbot Molecular) using the Nick Translation Mix (Abbot Molecular). This probe contained three units of the 5S rRNA gene (120 bp) and the noncoding intergenic spacers (about $290 \mathrm{bp})$. DNA in situ hybridisation was carried out according to Heslop-Harrison et al. (1991) and Cerbah et al. (1998) with slight modifications as follows. Slides were 
incubated in $100 \mu \mathrm{g} / \mathrm{ml}$ DNase-free RNase in 2×SSC (0.03 M sodium citrate and $0.3 \mathrm{M}$ sodium chloride) for $1 \mathrm{~h}$ at $37^{\circ} \mathrm{C}$ in a humidified chamber, rinsed in $2 \times \mathrm{SSC}$ for 5 min with slow shaking, and incubated in pepsin $(0.1 \mathrm{mg} / \mathrm{ml}$ in $0.01 \mathrm{~N} \mathrm{HCl})$ for $15 \mathrm{~min}$ at $37^{\circ} \mathrm{C}$, washed three times in $2 \times S S C$ for 5 min each with slow shaking, dehydrated through an ice-cold ethanol series (70\%, 90\%, and $100 \%$ for 3 min each), and air dried. The probe hybridisation mixture contained $25-100 \mathrm{ng} / \mu \mathrm{l}$ rDNA probes, formamide, $50 \%(\mathrm{w} / \mathrm{v})$ dextran sulphate, and $20 \times \mathrm{SSC}$. This was denatured at $75^{\circ} \mathrm{C}$ for $10 \mathrm{~min}$ and immediately transferred to ice for $5 \mathrm{~min}$. Approximately $30 \mu \mathrm{l}$ of the probe mixture were loaded on slides and covered with plastic coverslips. The preparations were denatured at $75^{\circ} \mathrm{C}$ for $10 \mathrm{~min}$ and transferred at $55^{\circ} \mathrm{C}$ for $5 \mathrm{~min}$. Hybridisation was carried out overnight at $37^{\circ} \mathrm{C}$ in a humidified chamber. Post-hybridisation washes were performed with shaking, the first at room temperature in $2 \times S S C$ for $3 \mathrm{~min}$, followed by several washes at $42^{\circ} \mathrm{C}$ for 5 min (three in $2 \times S S C$, one in $0.1 \times$ SSC, three in $2 \times$ SSC and one in $4 \times$ SSC with $0.2 \%$ Tween 20). A last wash was done at room temperature for $7 \mathrm{~min}$ in $4 \times \mathrm{SSC}$ with $0.2 \%$ Tween 20 . Samples were counterstained with Vectashield (Vector Laboratories, Inc. Burlingame, California) a mounting medium containing DAPI. FISH preparations were observed with an epifluorescence Zeiss Axioplan microscope with different combinations of Zeiss excitation and emission filter sets (01,07 and 15). Hybridisation signals were analyzed and photographed using the highly sensitive CCD camera (Princeton Instruments), images were processed for color balance, contrast and brightness uniformity with Adobe Photoshop Axiovision HR Rev3, 4.8. Graphics (idiograms) were performed with PowerPoint 2010, considering three standard chromosome sizes (small, medium and large). 
Flow cytometric measurements

Seven populations of the different Calligonum species were studied, and of these, five individuals per population were selected to estimate the genome size by flow cytometry (Table 2). We used both seeds and leaves from seedlings for these analyses and each individual was measured twice. Petunia hybrida Vilm. 'PxPc6' $(2 \mathrm{C}=2.85 \mathrm{pg}$; Marie and Brown 1993) and Lycopersicon esculentum Mill. 'Montfavet 63-5' (2C = 1.99 pg; Catrice et al. 2006) were used as the internal standards, which were first analyzed separately to locate its peak position at the fluorescence histogram. Fresh leaf tissue of the standard and the target species were chopped together in $600 \mu$ l of LB01 buffer (8\% Triton X-100; Doležel et al. 1989) supplemented with $100 \mu \mathrm{g} / \mathrm{ml}$ ribonuclease A (RNase A, Boehringer, Meylan, France) and stained with $36 \mu \mathrm{l}$ of $1 \mathrm{mg} / \mathrm{ml}$ propidium iodide (Sigma-Aldrich, Alcobendas, Madrid) to a final concentration of $60 \mu \mathrm{g} / \mathrm{ml}$, and kept on ice for $20 \mathrm{~min}$. The fluorescence measurements were performed using an Epics $\mathrm{XL}$ flow cytometer (Coulter Corporation, Miami, FL, USA) at the Centres Científics i Tecnològics, Universitat de Barcelona. More details about the method followed are described in Gouja et al. (2014). As in Garcia et al. (2008), to ensure that the instrument shows a linear response across the range of genome sizes studied and that results obtained with either one internal standard or the other are fully comparable, we performed cytometric assays with both internal standards and the specimen with the highest genome size at the same time. The difference between the obtained results with respect to each standard was negligible (about $1.5-2 \%$ of deviation), and we can therefore ascertain the linearity 


\begin{abstract}
of the flow cytometer in this interval and the convenience of the use of the chosen internal standards in any case.
\end{abstract}

\title{
Statistical analyses
}

In order to detect significant difference between genome size estimations from seeds and leaves from seedlings, the non-parametric Wilcoxon test for paired data and the parametric paired t-test were performed with XLSTAT (Addinsoft) and the R commander package (Version 2.0-3) of $R$.

\section{Results}

Basic karyology

The metaphase chromosome morphology of the studied species is shown in Fig. 2. Basic chromosome number of all species was $x=9$. All observations showed that $C$. comosum (Kamour), C. azel (Tiarert and El Borma) and C. arich (Kamour) have a somatic number of $2 n=18$ (diploid), whereas, for C. comosum (El Borma) we have detected diploid and tetraploid cytotypes (Fig. 2: g, m): $2 n=18$ and $2 n=36$ (Table 1). We find metacentric, submetacentric and acrocentric chromosomes in Calligonum metaphases. 
rDNA FISH and fluorochrome banding

The cytogenetic results of the taxa studied are presented in Fig. 2. In all the studied Calligonum species, $5 \mathrm{~S}$ and $35 \mathrm{~S}$ signals were always in different chromosomes, separated from each other (S-type arrangement). Calligonum arich, C. azel and C. comosum (Kamour) have one locus of 35S rDNA and two loci of 5S rDNA (Fig. 2: b and c, e and $f$, and $k$ and $I$, respectively) whereas the diploid C. comosum (El Borma) has two loci of 355 rDNA and one locus of 5S rDNA (Fig. 2: h, i). The tetraploid C. comosum (EI Borma) presents two loci of both the $35 \mathrm{~S}$ and $5 \mathrm{~S}$ rDNAs (Fig. 2:n, o). GC-rich regions were detected in all the studied species with CMA staining, which showed six terminal bands in all diploids and eight terminal bands in the tetraploid C. comosum from El Borma, in all cases in different chromosomes and coincident with rDNA sites (data not shown).

\section{Genome size}

Although genome size measurements for Calligonum species were apparently similar in seeds and in leaves, the paired t-student test and the Wilcoxon test for paired data supported significant differences between both datasets ( $p<0.05$ for both). In all cases, values obtained with seeds were slightly higher than those obtained with leaves. The $2 \mathrm{C}$ DNA mean values ranged from 2.58 to $2.63 \mathrm{pg}$ (for seeds) and from 2.27 to $2.56 \mathrm{pg}$ (for leaves), and, at the tetraploid level, the values were $4.89 \mathrm{pg}$ (for seeds) and $4.77 \mathrm{pg}$ (for leaves) (Table 2). Half-peak coefficients of variation (HPCV) values were lower than $5 \%$ in all cases, which indicates the good quality of the analyses. 


\section{Discussion}

Chromosome number

Cytogenetic studies by Hong et al. (1992), Navajas-Pérez et al. (2005), and Baltisberger and Widmer (2006) have revealed highly variable basic chromosome numbers in Polygonaceae ( $x=7$ to 13 ), in particular in the genera Rumex and Polygonum (Simmonds 1945; Baltisberger and Widmer 2006). Chromosomal studies are particularly difficult to perform in Calligonum due to the small chromosome size. The chromosome numbers of genus Calligonum had been previously investigated and our results confirm the basic chromosome number of $x=9$ and the existence of two cytotypes, $2 n=18$ and $2 n=36$. The chromosome number for $C$. arich is reported here for the first time. Although these diploid and tetraploid cytotypes are the most commonly found in the genus (Sabirhazi and Pan 2009; and references therein), recently, Shi et al. (2013) reported a triploid population ( $2 n=3 x=27)$ in C. mongolicum Turcz., supporting what Mao et al. (1983) had already stated that polyploidy was present in the genus, including triploid and tetraploid forms. They had also detected an unusual count $(2 n=24)$, which would point to aneuploidy, in a population of $C$. klementzii Losinsk.

General banding and rDNA pattern in Calligonum species 
In the Polygonaceae, the independent organization of $5 S$ and $35 S$ rDNA loci on chromosomes, i.e. that both rRNA genes are separated, not linked in a single operon as found in genera such as Artemisia, some other Asteraceae or Ginkgo, among others (Garcia et al. 2009, 2010; Galián et al. 2012; Garcia and Kovař́ík 2013), had been previously observed (Sheng et al. 2013). FISH studies on family Polygonaceae are rare and this is the first molecular cytogenetic investigation in Calligonum. Our FISH results have shown that all $5 \mathrm{~S}$ and $35 \mathrm{~S}$ rDNA sites were also separated and always located in terminal positions of different chromosomes. Actually, rRNA genes (particularly 35S) occur preferentially in terminal positions in angiosperms (Roa and Guerra 2012). These regions were always positively stained with $\mathrm{CMA}$, which is also a common finding as rDNA is typically GC-rich (Garcia et al. 2009). In diploids, the general pattern is that two terminal 5S rDNA sites and four terminal 35S rDNA sites are observable. However, there is an exception in the diploid C. comosum (El Borma), where we find the inverse result. Plenty of studies on variation in number of rDNA loci in many plant, insect and vertebrate groups have described such changes in their number and chromosomal location, suggesting that rDNA sites are highly dynamic components of the genome (Britton-Davidian et al. 2012). The tetraploid cytotype of C. comosum shows equal numbers of sites (four) for both $5 \mathrm{~S}$ and $35 \mathrm{~S}$ rDNA. Chromosomes with $35 \mathrm{~S}$ rDNA genes are called NOR-bearing (nucleolar organizer regions) chromosomes, these are the regions around which the nucleolus forms after mitosis. When these genes are transcriptionally active (competent NORs, Kalmarová et al. 2007) they give rise to decondensed chromatin structures during previous interphase and prophase and to secondary constrictions at metaphase stage. When these are inactive (i. e. silent) they 
are often highly compacted. Due to the reduced size of Calligonum chromosomes, the presence of secondary constrictions (in other words, the number of $35 \mathrm{~S}$ sites that are transcriptionally active) is difficult or impossible to see. However, in the slightly prophasic chromosomes shown for C. azel (Fig. 2e) we can see two 35S chromatin knobs (i. e. satellites) apparently detached (indicated with arrows) but which may be connected to their respective chromosomes by faint fibers of decondensed heterochromatin. We assume that these are competent NORs, and therefore one $35 \mathrm{~S}$ rDNA locus would be active for this species, while the other remains inactive, a phenomenon known as amphyplasty or nucleolar competence and which could be related to past hybrid origin of the species / population (Lacadena et al. 1984). Altogether, rather than a specific cytogenetic pattern, capable of discerning between these three taxa, we find a typical karyotype common to $C$. arich, $C$. azel and $C$. comosum. Conversely, the clade formed by these tree taxa in a recent phylogenetic reconstruction based on nuclear (ITS) and plastid (trnL-trnF and $r b c \mathrm{~L}$ ) regions (Gouja et al. 2014) did clearly discern between the three species (see Figure 3), supporting their separated specific status. Similar findings were reported in the Tridentatae subgenus of Artemisia (Garcia et al. 2009). In this species complex, a quite homogeneous cytogenetic pattern was shared among its members, although phylogenetic approaches clearly supported the specific status of these species (Garcia et al. 2011).

Previous research determining the number and location of $5 S$ and $35 S$ ribosomal DNA loci distribution in Polygonaceae does not show a clear tendency of $5 S$ or 355 loci to be in higher or lower abundance than the other; in Fagopyrum and Persicaria most species present more 35 S than 5 S loci (Kikuchi et al. 2008; Sheng et al. 2013; Choi et al. 2008), 
while in Rumex it is the other way round (Koo et al. 2004; Kim et al. 2006). Nevertheless, the number of rDNA sites detected for Calligonum is consistent with the most commonly found numbers in angiosperms. In this line, the typical angiosperm karyotype at the diploid level, according to data available at the Plant rDNA database (www.plantrdnadatabase.com, Garcia et al. 2012) has 18 chromosomes with two 5S sites and two to four $35 \mathrm{~S}$ sites (being four the most usual), both kinds located at terminal position (Garcia et al. unpublished research).

Polyploidy, rDNA loci downsizing and intraspecific rDNA loci number variation

Polyploidy is a common phenomenon in plants and has contributed to the evolution of about $70 \%$ of angiosperms species (Cui et al. 2006; Leitch and Leitch 2008; Soltis et al. 2009; Garcia et al. 2009; Ramsey and Schemske 1998). Among many other features, polyploidy is said to improve fitness in arid habitats (Grant 1981). In our sample, C. comosum (El Borma) has the largest geographical distribution, spread across the Sahara with the exclusion of the Great Erg Oriental to the high Southern plains, with an extension to the East and North of Tunisian desert. On the other side, $C$. arich is an endemic restricted, with a low frequency of distribution (one to five plants per ha), to the top of the large dunes of the Great Erg Oriental. Calligonum azel is also localized at the Great Erg Oriental (Le Houérou 1959) occupying the slopes of large Saharan dunes (Dhief et al. 2009) with a poor average density of one to 10 plants per ha. It is likely that the tetraploid cytotype of $C$. comosum has achieved a larger geographical distribution (Ferchichi 1997) than the others, only known at diploid level. 
Regarding the number of rDNA sites, we would expect that the tetraploid C. comosum would have twice the number of rDNA signals than the diploid ones. However, neither from "doubling" the number of signals from the diploid C. comosum individuals from EI Borma nor from the population of Kamour, the observed number of signals, that is four sites both for $5 \mathrm{~S}$ and $35 \mathrm{~S}$ rDNA, is not consistent with a recent autopolyploid origin of any of them (and this is also consistent with regards to the number of CMA positive signals: we would expect 12 but we only detect eight GC-rich bands). According to our results, there has been loss in any case. Loci loss has been previously detected after allopolyploid and autopolyploid formation (Garcia et al. 2009), although rDNA loci additivity (i.e. that the tetraploids have twice the number of loci than the diploids, for example) is also a common finding, particularly in polyploids of recent origin (Soltis and Soltis 1999).

As stated previously, there is intraspecific variability in $C$. comosum, which may be a reflection of the higher ecological plasticity and colonising ability of this species with respect to $C$. azel and $C$. arich. A variable number of rDNA sites occur between different populations of $C$. comosum, a case of intraspecific variability, quite commonly found in many plant groups. Two authors have determined the number and location of the $35 \mathrm{~S}$ and $5 S$ rRNA loci in Polygonaceae, also finding a variation in the number of the rDNA sites in Fagopyrum esculentum: Kikuchi et al. (2008) reported the presence of six signals of both 35 S and 5S rDNA, but Sheng et al. (2013) detected eight 35S rDNA and four 5S rDNA sites. A considerable variation in rDNA loci number was also identified in the 
species Rumex acetosa: according to Kim et al. (2006), it presented four $35 \mathrm{~S}$ and $5 \mathrm{~S}$ rDNA sites, while Koo et al. (2004) showed two 5S rDNA sites and three to four 35S rDNA sites. Many other examples outsides family Polygonaceae can be found showing that intraspecific variation in the number of rDNA loci is a common finding (Garcia et al. 2012).

Genome size analysis

This is the first time that the amount of nuclear DNA was assessed in Calligonum from seed tissue. The results confirm the chromosomal counts, indicating that $C$. comosum (EI Borma) has two cytotypes (diploid and tetraploid). Among the diploid taxa, genome sizes are fairly similar, i.e. genome size alone would not help distinguishing between these species. The flow cytometry profiles of nuclear DNA content obtained both for seeds and leaf tissue show that $2 \mathrm{C}$-values in seeds were slightly but significantly higher $(p<0.05)$ than in the leaves in all cases. A similar situation had been observed previously in Brassica napus L. and Helianthus annuus L. (Sliwinska et al. 2005) and in Eucalyptus globulus Labill. (Pinto et al. 2004), in which a higher genome size was found in seeds than in leaves. Many angiosperms contain a storage tissue, named endosperm, full of reserve for the embryo and which, in diploid species, it is triploid. This could interfere with genome size estimations from seeds. However, our results indicate that the measurements clearly correspond to the embryo cells, since values from seeds are only $1.5 \%$ to $15.8 \%$ larger than values from leaf tissue, depending on the species. If we were measuring mostly endospermic cells we would expect values about $50 \%$ larger in seeds 
than in leaves. This was also the case of Zea mays L. (Sliwinska et al. 2005) in which no endosperm nuclei were observed in the histograms as a clear fluorescence peak when the whole seed was analyzed, because the large storage cells of endosperm do not contain nuclei. This is probably what explains the relatively similar genome sizes between seeds and leaves in Calligonum.

Additionally, results were overall consistent with previous genome size determination in these species from leaves $(2.30 \mathrm{pg}$ for C. azel, $2.45 \mathrm{pg}$ for C. arich and $4.68 \mathrm{pg}$ for tetraploid C. comosum, from Gouja et al. 2014). According to several authors (Bino et al. 1993; Sliwinska et al. 2009), species that contain phenolic compounds, among others, may present technical problems for measurements with flow cytometry. Many species, particularly woody and aromatic plants, produce numerous secondary metabolites that can interfere with DNA staining causing stoichiometric error in measurements. Calligonum is rich in polysaccharides, alkaloids and other secondary metabolites (Liu et al. 2001). Thus, the lower DNA content in leaves could be explained by the presence of interfering staining inhibitors (Sliwinska et al. 2005). Other authors (Baluska 1990; Biradar and Rayburn 1994) suggested that the difference between the $2 \mathrm{C}$ values in leaves and seeds could be due to the different structure and condensation of chromatin in these different tissues.

Genome size in the tetraploid C. comosum $(2 \mathrm{C}=4.89 \mathrm{pg})$ is $6 \%$ lower than expected from doubling nuclear DNA amount from its closest diploid relative $(2 \mathrm{C}=2.59 \mathrm{pg})$. Genome downsizing is a widespread biological phenomenon in response to polyploidisation, leading to diploidisation of the polyploid genome (Leitch and Bennett 
2004). There may be a relationship between the detected genome downsizing in the tetraploid and its lower than expected number of rDNA loci previously described. Although the whole genome downsizing cannot be directly linked (neither totally attributed) to a decrease in the number of rDNA loci (or rDNA genes copy number) it is conceivable that rDNAs, as a highly repetitive part of the genome, bear some relationship with overall genome size (Prokopovich et al. 2003).

\section{Conclusions}

This study reports for the first time data on ribosomal DNAsite number and distribution in a representative sample of Calligonum species in the desert areas of Tunisia. This supports a typical signal pattern at the diploid level with mostly two terminal 5S rDNA and four terminal $35 \mathrm{~S}$ rDNA sites. Nevertheless, more species and populations should be analysed in order to confirm this model, since we found some intraspecific variation for one species. In the tetraploid studied, rDNA loci loss and genome downsizing have been detected, both findings frequently associated with polyploidy. Finally, the study demonstrated that genome size can be estimated from seeds in these taxa, and that this estimate may be more accurate than from leaves since seeds do not contain staining inhibitors, while leaves may present cytosolic compounds that interfere with the genome size assessment. As the slight difference in genome size estimations from seeds and leaves is significant, we recommend the use of seeds for nuclear DNA assessments in this genus and probably as well in closely related taxa, whenever possible. 


\section{Acknowledgements}

This work was supported by the Dirección General de Investigación Científica y Técnica, government of Spain (CGL2010-22234-C02-01/BOS and CGL2010-22234-C02-02/BOS) and the Generalitat de Catalunya, government of Catalonia ("Ajuts a grups de recerca consolidats", 2009SGR0439). SG and OH benefitted from Juan de la Cierva postdoctoral contracts of the Ministry of Economy and Competitiveness, government of Spain. Prof. Joan Vallès is thanked for the critical reading and suggestions on the manuscript. Dr. Aleš Kovařík is acknowledged for supplying the rDNA probes, Dr. Spencer C. Brown for supplying internal standards for flow cytometry and Daniel Vitales for assessment in the statistical analyses. We thank the technical staff of the Range Ecology Laboratory, Arid Lands Institute of Médenine, who helped us to develop the fieldwork. Ricard Àlvarez, Jaume Comas, Chari González and Sonia Ruiz are acknowledged for their assistance in flow cytometric analyses, and Alastair Plant for the English text revision. 
Table 1 Provenance and collection data of the studied Calligonum populations, all from Tataouine, Tunisia. All signals appear in terminal or subterminal positions. $\left({ }^{*}\right)$ Chromomycin $A_{3},\left({ }^{* *}\right)$ detected with 265 rDNA probe.

\begin{tabular}{|c|c|c|c|c|c|c|c|}
\hline Taxon & Voucher specimens & Collection year & $\begin{array}{l}\text { Chromosome } \\
\text { number (2n) }\end{array}$ & $\begin{array}{l}\text { Ploidy } \\
\text { level }\end{array}$ & CMA* & $\begin{array}{c}5 S \text { rDNA } \\
\text { sites }\end{array}$ & $\begin{array}{c}35 S \text { rDNA } \\
\text { sites** }\end{array}$ \\
\hline C. arich & Tunisia, Tataouine: Kamour, Gouja H. BCN 106466 & 2005 & 18 & $2 x$ & 6 & 2 & 4 \\
\hline C. azel & Tunisia, Tataouine: Tieret, Gouja H. BCN 106463 & 2012 & 18 & $2 x$ & 6 & 2 & 4 \\
\hline C. azel & Tunisia, Tataouine: El Borma, Gouja H. BCN 106465 & 2010 & 18 & $2 x$ & 6 & 2 & 4 \\
\hline C. comosum & Tunisia, Tataouine: Kamour, Gouja H. BCN 106456 & 1999 & 18 & $2 x$ & 6 & 2 & 4 \\
\hline C. comosum & Tunisia, Tataouine: El Borma, Gouja H. BCN 106457 & 2007 & 18,36 & $2 x, 4 x$ & 6,8 & 4,4 & 2,4 \\
\hline
\end{tabular}


Table 2 Genome size data of the studied Calligonum populations, all from Tataouine, Tunisia. SD= standard deviation. Lycopersicon esculentum* $(2 \mathrm{C}=1.99 \mathrm{pg})$ and Petunia hybrida** $(2 \mathrm{C}=2.85 \mathrm{pg})$ were used as internal standards.

\begin{tabular}{|c|c|c|c|c|c|c|c|}
\hline Taxon & Voucher specimens & Collection year & Poidy level & $\begin{array}{c}2 C(p g) \pm S D \\
\text { seeds }\end{array}$ & $\begin{array}{c}\text { HPCV plant } \\
\text { (\%) }\end{array}$ & $\begin{array}{l}2 C(p g) \pm S D \\
\text { seedlings }\end{array}$ & $\begin{array}{c}\text { HPCV plant } \\
\text { (\%) }\end{array}$ \\
\hline \multirow[t]{2}{*}{ C. comosum } & Tunisia, Tataouine: Kamour, Gouja H. BCN-S-1887 & 2013 & $2 x$ & $2.59 \pm 0.07 *$ & 3.45 & $2.36 \pm 0.07^{* *}$ & 3.16 \\
\hline & Tunisia, Tataouine: El Borma, Gouja H. BCN-S-1877 & 2012 & $4 x$ & $4.89 \pm 0.13^{*}$ & 3.28 & $4.77 \pm 0.10^{* *}$ & 3.94 \\
\hline \multirow[t]{3}{*}{ C. azel } & Tunisia, Tataouine: Kamour, Gouja H. BCN-S-1888 & 2013 & $2 x$ & $2.63 \pm 0.20^{*}$ & 3.70 & $2.27 \pm 0.06^{* *}$ & 3.63 \\
\hline & Tunisia, Tataouine: El Borma, Gouja H. BCN-S-1876 & 2012 & $2 x$ & $2.60 \pm 0.13^{*}$ & 3.93 & $2.45 \pm 0.05^{* *}$ & 1.71 \\
\hline & Tunisia, Tataouine: Tieret, Gouja H. BCN-S-1874 & 2012 & $2 x$ & $2.58 \pm 0.08 *$ & 3.04 & $2.54 \pm 0.02 * *$ & 3.18 \\
\hline \multirow[t]{2}{*}{ C. arich } & Tunisia, Tataouine: Kamour, Gouja H. BCN-S-1889 & 2013 & $2 x$ & $2.60 \pm 0.10^{*}$ & 2.37 & $2.45 \pm 0.07 *$ & 2.39 \\
\hline & Tunisia, Tataouine: El Borma, Gouja H. BCN-S-1878 & 2012 & $2 x$ & $2.60 \pm 0.13^{*}$ & 1.34 & $2.56 \pm 0.01^{*}$ & 4.97 \\
\hline
\end{tabular}


Fig. 1 Map of Tunisia indicating the geographical distribution of the Calligonum populations analysed.

Fig. 2 Orcein, FISH pictures and idiograms in which chromomycin $A_{3}$ positive bands are marked yellow, 26S rDNA sites, green and 5S rDNA sites, red, for diploid Calligonum arich from Kamour (a-c), C. azel from El Borma (d-f), C. comosum from El Borma (g-i), C. comosum from Kamour ( $\mathrm{j}-\mathrm{I})$ and tetraploid C. comosum from El Borma (m-o). Since information on chromosome morphology is not included in this work, idiograms depict them as all metacentric, although submetacentric and acrocentric chromosomes are also present. In picture e arrows indicate detached 35S rDNA satellites. Scale bars $=10$ $\mu \mathrm{m}$.

Fig. 3 Neighbour-net diagram based on sequences from the merged dataset of three DNA regions (ITS, trnL-F, and $r b c \mathrm{~L}$ ), adapted from Gouja et al. (2014). Populations of the same species are grouped in the same cluster. 


\section{References}

Ali HBM, Meister A, Schubert I (2000) DNA content, rDNA loci and DAPI bands reflect the phylogenetic distance between Lathyrus species. Genome 43: 1027-1032

Baltisberger M, Widmer A (2006) Chromosome numbers of plant species from the Canary Islands. Bot Helv 116: 9-30 doi: 10.1007/s00035-006-0739-x

Badria FA, Ameen M, Akl MR (2007) Evaluation of cytotoxic compounds from Calligonum comosum L. growing in Egypt. Z Naturforschung C 62: 656-660

Baluska F (1990) Nuclear size, DNA content, and chromatin condensation are different in individual tissues of the maize root apex. Protoplasma 158: 45-52

Bao BJ, Grabovskaya-Borodina AE (2003) Calligonum L. In: Wu ZY, Raven PH (eds) Flora of China, vol 5, Science Press, Beijing and Missouri Botanical Garden Press, St. Louis, pp 324-328

Bino RJ, Lanteri S, Verhoeven HA, Kraak HL (1993) Flow cytometric determination of nuclear replication stages in seed tissues. Ann Bot 72: 181-187 doi: 10.1006/anbo.1993.1097

Biradar DP, Rayburn AL (1994) Flow cytometric probing of chromatin condensation in maize diploid nuclei. New Phytol 126: 31-35 doi: 10.1111/j.14698137.1994.tb07526.x 
Bolkhovskikh Z, Grif V, Matvejeva T, Zakharyeva O (1969) Chromosome numbers of flowering plants. Academy of Sciences of the USSR, Leningrad

Britton-Davidian J, Cazaux B, Catalan J (2012) Chromosomal dynamics of nucleolar organizer regions (NORs) in the house mouse: micro-evolutionary insights. J Hered 108: 68-74 doi:10.1038/hdy.2011.105

Catrice O, Coba de la Pena T, Brown SC (2006) Applications en biologie végétale: contraintes, succès, espoirs. In: Ronot X, Grunwald D, Mayol JF, Boutonnat J (eds) La Cytométrie en Flux, Tec and Doc - Lavoisier, Paris, pp 235-253

Cerbah M, Coulaud J, Brown SC, Siljak-Yakovlev S (1998) Evolutionary DNA variation in the genus Hypochaeris. J Hered 89: 312-318 doi: 10.1046/j.13652540.1999.00469.x

Cerbah M, Coulaud J, Godelle B, Siljak-Yakovlev S (1995) Genome size, fluorochrome banding, and karyotype evolution in some Hypochaeris species. Genome 38: 689695

Choi HW, Lee SH, Kim SY, Bang JW (2008) Karyotypic analysis and physical mapping of rRNA gene loci in Persicaria tinctoria. Korean J Med Crop Sci 16: 195-198

Cui L, Wall PK, Leebens-Mack J, Lindsay BG, Soltis DE, Doyle JJ, Soltis P, Carlson JE, Arumuganathan K, Barakat A, Albert VA, Ma H, dePamphilis CW (2006) Widespread genome duplications throughout the history of flowering plants. Genome Res 16: 738-749 
Darlington CD, Wylie AP (1955) Chromosome atlas of flowering plants. George Allen and Unwin Ltd., London

Dhief A, Gorai M, Aschi-Smiti S, Neffati M (2009) Comparative phenological and water potential patterns of three Calligonum species in the eastern Great Erg of Tunisia. Flora 204: 581-592 doi: 10.1016/j.flora.2008.07.007

Dhief A, Gorai M, Aschi-smiti S, Neffati M (2012) Effects of some seed-coat dormancy breaking treatments on germination of three Calligonum species occurring in Southern desert of Tunisia. Ecol Med 38: 19-27

Doležel J, Binarova P, Lucretti S (1989) Analysis of nuclear-DNA content in plant-cells by flow-cytometry. Biol PI 31: 113-120 doi : 10.1007/BF02907241

Ferchichi A (1997) Contribution à l'étude caryologique, caryosystématique, morphologique et écologique de la flore de la Tunisie présaharienne. Faculté des Sciences de Tunis, Thèse de doctorat

Galián JA, Rosato M, Rosselló JA (2012) Early evolutionary colocalization of the nuclear ribosomal $5 \mathrm{~S}$ and $45 \mathrm{~S}$ gene families in seed plants: evidence from the living fossil gymnosperm Ginkgo biloba. Heredity 108: 640-646 doi: $10.1038 /$ hdy.2012.2

Garbari F, Bedini G, Peruzzi L (2012) Chromosome numbers of the Italian flora. From the Caryologia foundation to present. Caryologia 65: 62-71 doi: $10.1080 / 00087114.2012 .678090$ 
Garcia S, Canela MÁ, Garnatje T, McArthur ED, Pellicer J, Sanderson SC, Vallès J (2008) Evolutionary and ecological implications of genome size in the North American endemic sagebrushes and allies (Artemisia, Asteraceae). Biol J Linn Soc 94:631649. doi: 10.1111/j.1095-8312.2008.01001.x

Garcia S, Lim KY, Chester M, Garnatje T, Pellicer J, Vallès J, Leitch AR, Kovařík A (2009) Linkage of $35 \mathrm{~S}$ and 5S rRNA genes in Artemisia (family Asteraceae): first evidence from angiosperms. Chromosoma 118: 85-97 doi: 10.1007/s00412-008-0179-z

Garcia S, Panero J, Siroky J, Kovarik K (2010) Repeated reunions and splits feature the highly dynamic evolution of $5 \mathrm{~S}$ and $35 \mathrm{~S}$ ribosomal RNA genes (rDNA) in the Asteraceae family. BMC PI Biol 10: 176 doi: 10.1186/1471-2229-10-176

Garcia S, McArthur ED, Pellicer J, Sanderson SC, Vallès J, Garnatje T (2011) A molecular phylogenetic approach to western North America endemic Artemisia and allies (Asteraceae): untangling the sagebrushes. Am J Bot 98:638-53. doi: 10.3732/ajb.1000386

Garcia S, Garnatje T, Kovařík A (2012) Plant rDNA database: ribosomal DNA loci information goes online. Chromosoma 121: 389-394 doi: 10.1007/s00412-0120368-7

Geber G, Schweizer D (1987) Cytochemical heterochromatin differentiation in Sinapis alba (Cruciferae) using a simple air-drying technique for producing chromosome spreads. PI Syst Evol 158: 97-106 doi:10.1007/BF00936336 
Gouja H, García-Fernández A, Garnatje T, Raies A, Neffati M (2014) Genome size and phylogenetic relationships between the Tunisian species of the genus Calligonum (Polygonaceae). Turk J Bot 38: 13-21 doi: 10.3906/bot-1301-72

Grant V. 1981. Plant speciation. 2nd ed. Columbia University Press, New York

Heslop-Harrison JS, Schwarzacher T, Anamthawat-Jonsson K, Leitch AR, Shi M, Leitch IJ. (1991) In situ hybridisation with automated chromosome denaturation. Technique 3: 109-116

Hong DY (1990) Plant cytotaxonomy. Science Press, Beijing

Hong B, Barg R, Ho TD (1992) Developmental and organ-specific expression of an ABA and stress-induced protein in barley. PI Mol Biol 18: 663-674

Hu YP, Xie XL, Wen Q, Zhao XD, Wang L, Li Y (2007) Studies on karyotype of five populations of Rheum tanguticum. Acta Bot Yunn 29: 429-433

Islam MW, Zakaria MNM, Radhakrishnan R, Liu XM, Chen HB, Chan K, Habibullah M (1999) Effect of ethanolic extract of Calligonum comosum (Polygonaceae) on experimental induced gastric ulcers in Wistar albino rats. J Pharm 51: 102

IUCN (1997) The 2002 International Union for Conservation of Nature red list of threatened species. Retrieved from http://www.redlist.org/search/details.php? species=30386 13/11/2003 


\author{
Kalmárová M, Smirnov E, Mašata M, Koberna K, Ligasová A, Popov A, Raška I (2007) \\ Positioning of NORs and NOR-bearing chromosomes in relation to nucleoli. J \\ Struct Biol 160: 49-56 doi: 10.1016/j.jsb.2007.06.012
}

Kikuchi S, Matsui K, Tanaka H, Ohnishi O, Tsujimoto H (2008) Chromosome evolution among seven Fagopyrum species revealed by fluorescence in situ hybridisation (FISH) probed with rDNAs. Chrom Sci 11: 37-43

Kim SY, Choi HW, Koo DH, Lee WK, Lee J, Bang JW (2006) Characterization of eight Rumex species by FISH (fluorescence in situ hybridisation) and 5S rDNA spacer sequences. Korean J Gen 28: 243-251

Koo DH, Hur Y, Bang JW (2004) Variability or rDNA loci in dioecious Rumex acetosa L. detected by fluorescence in situ hybridisation. Korean J Gen 26: 9-13

Lacadena JR, Cermefio MC, Orellana J, Santos JL (1984) Evidence for wheat-rye nucleolar competition (amphiblasty) in triticale by silver staining procedure. Theor Appl Genet 67: 207-213

Le Houérou H (1959) Recherches écologiques et floristiques sur la végétation de la Tunisie méridionale. Institut des Recherches Sahariennes, Alger

Leitch IJ, Bennett MD (2004) Genome downsizing in polyploidy plants. Biol J Linn Soc 82: 651-663

Leitch IJ, Heslop-Harrison JS (1993) Physical mapping of the 18S-5.8S-26S rRNA genes in barley by in situ hybridisation. Genome 35: 1013-1018 
Leitch AR, Leitch IJ (2008) Genomic plasticity and the diversity of polyploid plants. Science 320: 481-483 doi 10.1126/science.1153585

Li D, Zhang X (2002) Physical localization of the 18S-5.8S-26S rDNA and sequence analysis of ITS regions in Thinopyrum ponticum (Poaceae: Triticeae): implications for concerted evolution. Am J Bot 90: 445-452

Lipscombe BA (1984) Golden days in the desert. Wild flowers of Saudi Arabia. IMMEL Publishing, Italy

Liu XM, Zakaria MNM, Islam MW, Radhakrishnan R, Ismail A, Chen HB, Chan K (2001) Anti-inflammatory and anti-ulcer activity of Calligonum comosum in rats. Fitoterapia 72: 487-491 doi: 10.1016/S0367-326X(01)00271-4

Liu JQ, Ho TN, Chen SL (2002) The first chromosome data documentations of Megacodon and Lomatogoniopsis and their systematic significance. Acta Biol PI Sin 15: $41-47$

Mao ZM, Pan BR (1986) The classification and distribution of the genus Calligonum L. in China. Acta Phytotaxon Sin 24: 98-107

Mao ZM, Yang G, Wang CG (1983) Studies on chromosome numbers and anatomy of young branches of Calligonum of Xinjiang in relation to the evolution of some species of the genus. Acta Phytotaxon Sin 21: 44-49

Marie D, Brown SC (1993) A cytometric exercise in plant DNA histograms, with 2C values for 70 species. Biol Cell 78: 41-51 
Navajas-Pérez R, De la Herrán R, Lopez Gonzales G, Jamilena M, Lozano R, Ruiz Rejon C, Ruiz Rejon M, Garrido-Ramos MA (2005) The evolution of reproductive systems and sex-determining mechanisms within Rumex (Polygonaceae) inferred from nuclear and chloroplastidial sequence data. Mol Biol Evol 22: 1929-1939

Pinto G, Loureiro J, Lopes T, Santos C (2004) Analysis of the genetic stability of Eucalyptus globulus Labill. somatic embryos by flow cytometry. Theor Appl Gen 109: 580-587 doi : 10.1007/s00122-004-1655-3

Pottier-Alapetite G (1979) Flore de la Tunisie. Angiospermes-dicotylédones: apétalesdialypétales-gamopétales. Première et deuxième partie. Ouvrage publié par le Ministère de l'Enseignement Supérieur et de la Recherche Scientifique et le Ministère de l'Agriculture, Tunisie

Prokopowich CD, Gregory TR, Crease TJ (2003) The correlation between rDNA copy number and genome size in eukaryotes. Genome 46: 48-50

Radhakrishnan R, Zakaria MNM, Islam MW, Chen HB, Liu XM, Chan K, Habibullah M (1999) Cardiovascular effects of Calligonum comosum extract in rat. J Pharm 51: 119

Raina SN, Mukai Y, Kawaguchi K, Goel S, Jain A (2001) Physical mapping of 18-5.8-26S and 5 S ribosomal RNA gene families in three important vetches (Vicia species) and their allied taxa constituting three species complexes. Theor Appl Gen 103: 839-845 
Ramsey JR, Schemske DW (1998) Pathways, mechanisms, and rates of polyploid formation in flowering plants. Ann Rev Ecol Syst 29:467-501

Ran Y, Hammett RW, Murray BG (2001) Phylogenetic analysis and karyotype evolution in the Genus Clivia (Amaryllidaceae). Ann Bot 87: 823-830 doi: $10.1006 /$ anbo.2001.1422

Roa F, Guerra M (2012) Distribution of 45S rDNA sites in chromosomes of plants: structural and evolutionary implications. BMC Evol Biol 12: 225 doi: $10.1186 / 1471-2148-12-225$

Sabirhazi G, Pan BR (2009) Chromosome numbers of three Calligonum species (Polygonaceae). Nordic J Bot 27: 284-286

Schuster TM, Setaro SD, Kron KA (2013) Age estimates for the buckwheat family Polygonaceae based on sequence data calibrated by fossils and with a focus on the Amphi-Pacific Muehlenbeckia. PloS ONE 8: e61261 doi: 10.1371/journal.pone.0061261

Schweizer D (1976) Reverse fluorescent chromosome banding with chromomycin and DAPI. Chromosoma 58: 307-324

Sheng M, Wang L, Tian X (2013) Identification of the full set of Fagopyrum esculentum trisomics by heterochromatin banding analysis and rDNA physical mapping. Sci Hortic Amsterdam 155: 15-23 
Shi W, Zhao Y, Kong F, Pan B (2013) Species redress in the Calligonum mongolicum complex (Polygonaceae) a multidisciplinary approach. Vegetos 2: 249-261

Simmonds NW (1945) Biological flora of the British Isles: Polygonum persicaria. J. Ecol. 33: 121-131. Singh G (2004) Influence of soil moisture and gradient on growth and biomass production of Calligonum polygonoides in Indian desert affected by surface vegetation. J Arid Envir 56: 541-558 doi: 10.1016/S0140-1963(03)00059-4

Singh RJ, Kim HH, Hymowitz T (2001) Distribution of rDNA loci in the genus Glycine Willd. Theor Appl Gen 103: 212-218

Sliwinska E, Pisarczyk I, Pawlik A, Galbraith DW (2009) Measuring genome size of desert plants using dry seeds. Botany 87: 127-135 doi:10.1139/B08-120

Sliwinska E, Zielinska E, Jedrzejczyk I (2005) Are seeds suitable for flow cytometric estimation of plant genome size? Cytometry Part A 64(2): $72-79$ doi: 10.1002/cyto.a.20122

Soltis DE, Albert VA, Leebens-Mack J, Bell CD, Paterson AH, Zheng C, Sankoff D, dePamphilis CW, Wall PK, Soltis PS (2009) Polypoidy and angiosperm diversification. Am J Bot 96: 336-348 doi: 10.3732/ajb.0800079

Soltis DE, Soltis PS (1999) Polyploidy: recurrent formation and genome evolution. Trends Ecol Evol 14: 348-352

Stebbins GL (1971) Chromosomal evolution in higher plants. Ed. Arnold, London, UK 
Stuessy TF (2011) Multiple sources of comparative data for creative monography. In: Stuessy TF, Lack HW (eds.) Monographic plant systematics. Fundamental assessment of plant biodiversity. Ruggell ARG Ganeter Verlag KG, pp 33-47

Wang CG, Guan XC (1986) The chromosome geographic distribution of Calligonum L. in Xinjiang. Arid Zone Res 2: 28-31

Wang CG, Yang G (1985) Investigation of chromosome number and chromosomal ploidy of Calligonum in Xinjiang. Arid Zone Res 1: 62-64

Zaki D, Abd-El-Aziz M, El-Gengeihy S, Morsi N (1984) Antimicrobial potentialities of some Egyptian desert plants. Herba Hung 23: 73-84

Zhang CS (1998) A preliminary study on making plant chromosomal specimens using peppermint oil compound as pretreatment agent. J Wuhan Bot Res 16: 280-282 


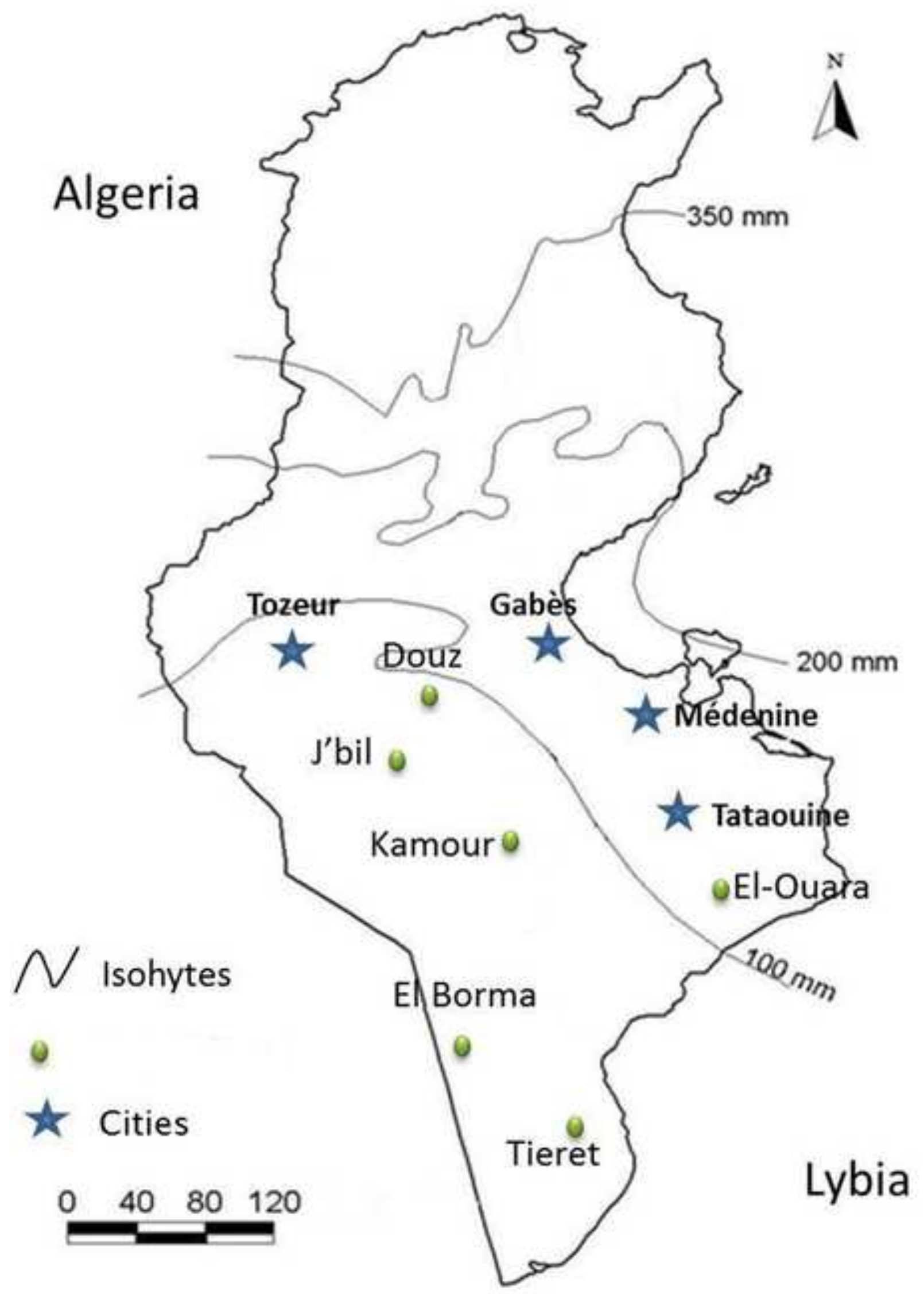



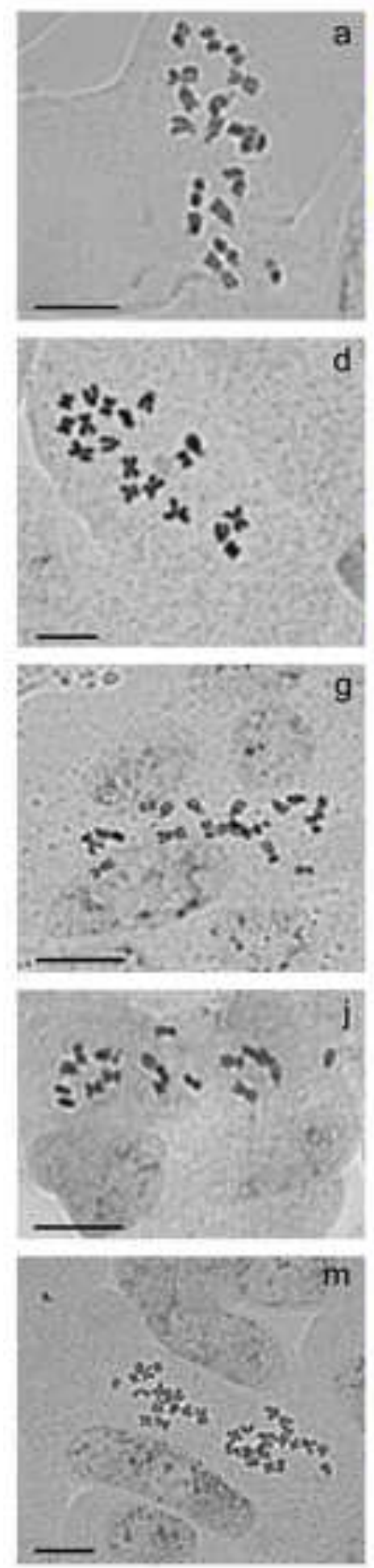
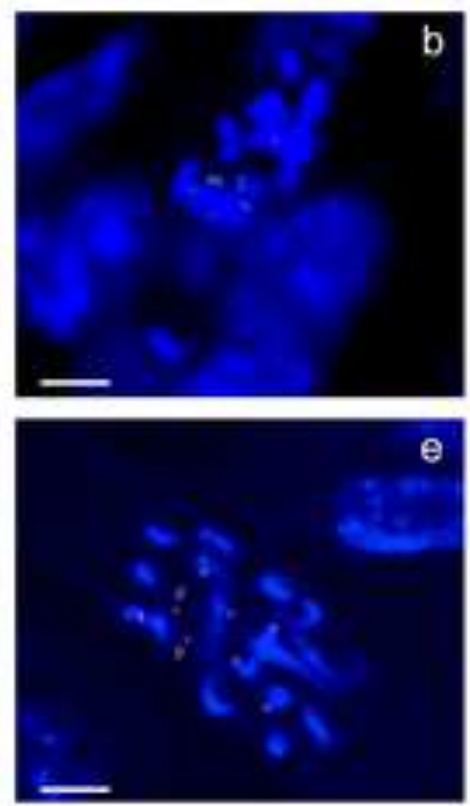

e
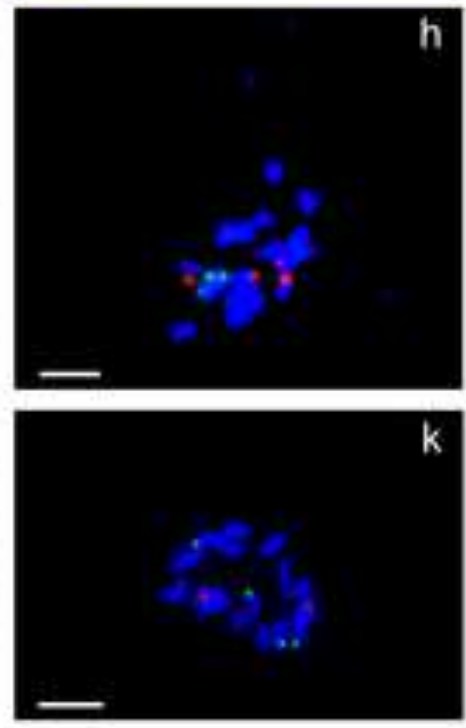

k

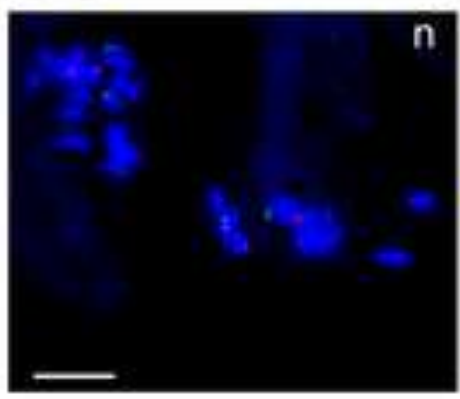

c
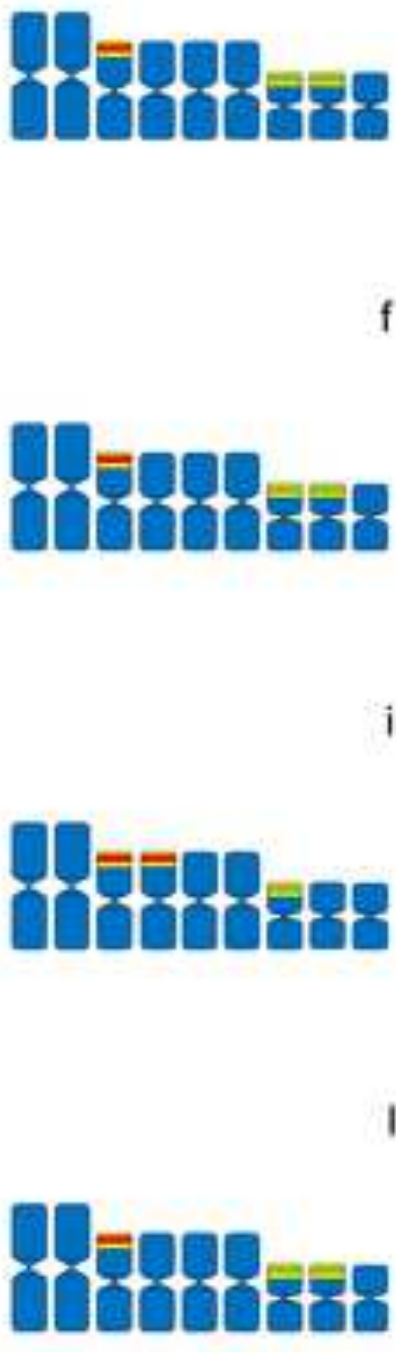

$\circ$

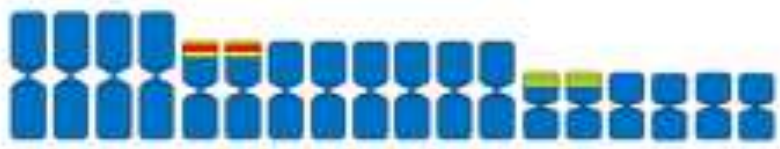




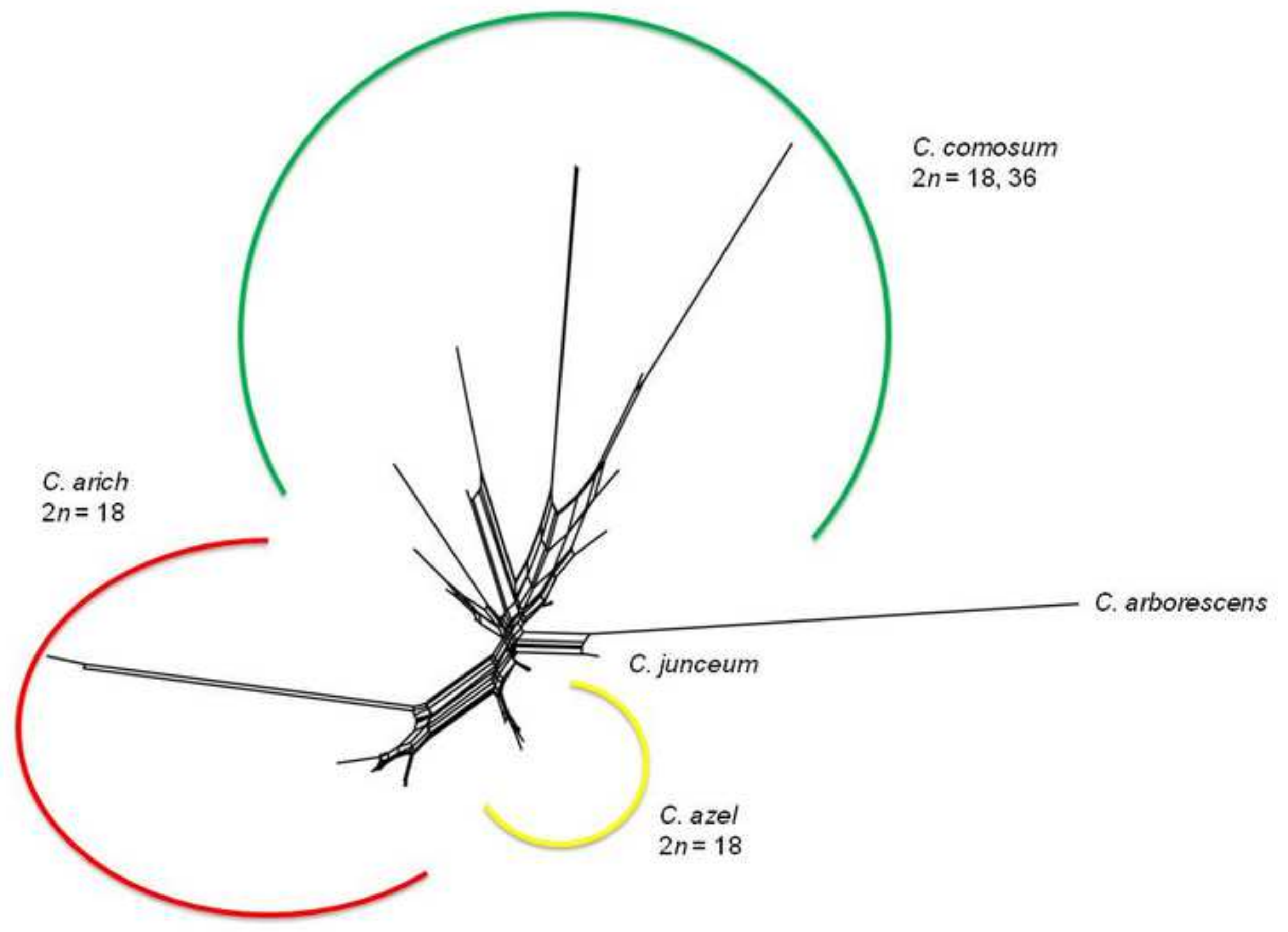

